\title{
Mapping media accountability in state- less nations: The case of Catalonia
}

\begin{abstract}
This article draws on the results of a research project on media accountability instruments in Catalonia. We map out media accountability in Catalonia focusing on institutional self-regulation instruments and outline their history compared to that of equivalent instruments in the rest of Spain and Europe. We discuss how the situation in Catalonia differs significantly from that of Spain in the context of Hallin and Mancini's media systems models. We argue that including the cultural domain in an analysis of media accountability provides a more accurate understanding of the media system in stateless nations. We conclude that the culture of journalistic accountability in Catalonia is more closely aligned with the Corporatist or Liberal model than with the Mediterranean one and thus that the economic and politi-cal spheres alone do not provide a true picture of national realities when assessing media accountability.
\end{abstract}

\section{KEYWORDS}

media accountability media ethics Catalonia self-regulation journalistic culture stateless nations

\section{Funding}

This work was supported by the Spanish Ministry of Economy and Competitiveness under Grant CSO2012-39138 (a three-year R+D project for 20132015). 


\section{Introduction}

As Philip Schlesinger noted (2009), states are a useful but limited analytical framework for the study of cultural and communication realities. This limitation comes not only from the challenges posed to cultural and communication sovereignty by global flows and transnational systems of governance, but also because the so-called nation states often contain multicultural, multi-ethnic and multinational societies that do not conform to a unified context. This diversity, of course, makes it harder to pin down the political economy of communication in any state. An already complex system is further compounded when there are distinctive national realities within a state - so-called 'stateless nations'. In this respect the term stateless nation can be accurately applied to Catalonia, which many regard as a nation within the Spanish state with its own history, language and culture that go back centuries (Sobrequés 2007; Eaude 2008; Harris 2014; Fontana 2016).

The communicative space within any liberal democracy, including stateless nations such as Catalonia, has at the very least three aspects: economic, sociocultural and political. The economic dimension is actually very homogeneous across western media systems, reflecting the ubiquitous logic of current financialized, informationalized capitalism (Almiron 2010). Communication media are a key industry for all European nations (for the size of the Catalan media system, see Civil i Serra et al. 2015). However, while the economic aspect of media might not vary significantly across Europe, the sociocultural and political dimensions certainly do. According to Daniel Hallin and Paolo Mancini (2004), the media systems in western democracies can be divided into three different types: the North/Central European or Democratic Corporatist model, the North Atlantic or Liberal model and the Mediterranean or Polarized Pluralist model. ${ }^{2}$ Spain is included in the Polarized Pluralist model, which, as the name suggests, is characterized by a high degree of politicization and external pluralism. In this model the media assume a role as advocates for various political ideologies (often identifying with specific political parties) and a commitment to these ideologies often outweighs commitment to a professional culture. Since Catalonia lacks its own state, Hallin and Mancini did not analyse the Catalan situation as such, although they do acknowledge that equating the situation in Catalonia with that of Spain is problematic.

Some authors have explored the discrepancy flagged up by Hallin and Mancini and have found evidence to suggest that the Catalan media do not fit the radical political polarization typical of the Spanish media (Alsius et al. 2011; Zallo 2013). According to Ramón Zallo (2013), Catalonia does exhibit some features of the polarized pluralist model, especially in the sense that its communication media reflect different sectors and political or economic interests directly. That is, the communication media in Catalonia do not fulfil the hypothetical role of safeguarding the quality of democracy by providing checks and balances and acting as a watchdog. However, Catalonia differs from the polarized pluralist model in other important aspects. According to Zallo, the peculiarities of the Catalan communicative space (like those of the Basque country and Galicia, the other stateless nations within Spain) are threefold: the existence of a nationalist axis, which is added to the traditional axis of the right/left social model; the fact that this nationalist axis takes precedence over the ideological axis; and the existence of a dual provision of media content, produced inside or outside of Catalonia. According to Zallo, this dual provision of content is 
disproportionately balanced in favour of the Spanish state offering with its accompanying Spanish identity. In this context, the home-grown part of the Catalan media system exhibits far less polarized pluralism than would be typical for the media systems categorized by Hallin and Marcini as polarized pluralist. Zallo defines the situation that arises from dual content in Catalonia as 'internally balanced' (2013: 276).

On the other hand, Hallin and Mancini do provide a sound basis for aligning the Catalan model with the rest of the Spanish media system if we only focus on the governance models of public broadcasters. In this respect, Maria Isabel Fernández-Alonso and Ana Fernández-Viso (2012) show how the Catalan model closely matches the Mediterranean model if we look at the level of government intervention in public media. After analysing the governance models of regional public service broadcasters in Spain, Fernández-Alonso and Fernández-Viso conclude that the governance in all of them is heavily influenced by the legacy of the Spanish Broadcasting Corporation Statute. They highlight the fact that while Catalonia is the only part of Spain to have made deep-rooted reforms aimed at removing government intervention, 'the results have so far been very disappointing' (2012: 216).

However, it should be noted that the role played by the Spanish public broadcaster during the return to democracy (embedded in the political struggles of the Spanish political transition) is not comparable to the role played by the Catalan public broadcaster (focused on the recovery of Catalonia's language and culture). Clear evidence for this is the very existence and promotion of the Catalan communicative space as a means to ground and rebuild the Catalan identity in the midst of a dominant Spanish culture, ${ }^{3}$ neo-liberal globalization and digitalization processes (Gifreu 2006; Zallo 2013).

This article argues that Catalonia's journalistic professional culture differs radically from the Mediterranean model and that we ought to speak of a communicative space that is distinctively Catalan in this respect. We provide evidence to support this claim by studying what is distinctive in the Catalan media system, namely self-regulation developed through independent media accountability instruments.

In particular, this article draws on the results of a research project aimed at mapping media accountability in Catalonia and Spain within the context of media accountability as an emerging research topic in the communications field. Our aim was to assess to what extent the institutional media accountability instruments in Catalonia fit into the Spanish Mediterranean model. As part of this project we identified institutional self-regulation instruments in Catalonia and then reconstructed their history compared to the rest of Spain and Europe.

In the following sections we introduce the theoretical framework for media accountability, our methodology and literature review. We then provide an account of the origins and evolution of institutional media accountability instruments in Catalonia. We conclude that taking into account the economic and political spheres alone does not provide a true picture of national realities and that the Catalan media system includes traits that are more closely aligned with the Liberal model of North-European states than with the Mediterranean model as defined by Hallin and Mancini. 


\section{Theoretical framework: Media accountability}

Western democracies have developed extensive legal frameworks for the communication and media industries in recent decades in an attempt to guarantee competition and pluralism (see, for instance, Mansell and Raboy 2014). Yet while structures have been mostly regulated - primarily in the audio-visual sector - journalism and the journalistic output is characterized by an absence of regulation as press freedom is considered a pillar of democratic societies (Christians et al. 2009). However, journalism is not a "game without rules": in many journalism cultures associations of journalism have adopted ethical codes ... detailing what conduct is expected of professional journalists' (Fengler et al. 2014: 16). This self-regulation is also referred to as informal institutions (laws being the formal institutions) or media accountability instruments.

According to Hallin and Mancini, in Mediterranean countries formal accountability systems are essentially absent. The highest levels of accountability systems are found in countries where the rational-legal authority is strongly developed and administrative apparatuses are fully accountable. In these cases, the instrumentalization of the press is weaker and journalism more professionalized since 'systems of rational-legal authority ... require formal codification of procedures and information, and their public accessibility, and thus provide relatively fertile ground for the development of journalism' (Hallin and Mancini 2004: 56).

Also Susan Fengler et al. (2014) - in what probably is the largest and most widereaching research on media accountability conducted in Europe so far - confirm that media accountability instruments barely exist in Southern Europe and are still emerging in Central and Eastern Europe, while in Anglo-Saxon and Northern European countries they have been established for a long time.

Tobias Eberwein et al. have defined media accountability instruments as 'any informal institution, both offline and online, performed by both media professionals and media users, which intends to monitor, comment on and criticize journalism and seeks to expose and debate problems of journalism' at the individual, media routines, organizational and extra-media levels (2011: 20). These authors provide the most-detailed typology so far. First, they classify media accountability instruments in the digital age as established instruments (press councils, ombudsmen, media journalism in trade journals, media criticism in the mass media, and letters to the editor, correction boxes, etc.) and innovative instruments (editorial weblogs, websites monitoring news content, webcasts of internal critique sessions, online ombudsmen and the media-critical activities on Twitter and Facebook) (2011: 9).

Another way of categorizing media accountability instruments, according to Eberwein et al., is by their degree of institutionalization. They argue that letters to the editors, ombudsmen, press councils, academic research, training, journalism relating to media and the work of NGOs (such as Reporters without Borders) have a high degree of institutionalization, whereas criticism of the media on social networks, citizen blogs, online comments or blogs written by journalists have a low degree of institutionalization.

Third, Eberwein et al. classify media accountability according to where the instruments originate: most of the instruments with a high degree of institutionalization are anchored inside the journalistic profession, whereas most 
of the instruments with a low degree of institutionalization are anchored outside the journalistic profession. It is interesting to note that the Internet has fostered the proliferation of media accountability instruments in this latter category and is providing the major innovations in terms of media transparency (Mauri-Ríos and Ramon-Vegas 2015).

\section{Literature review and methodology}

So far, the majority of research on media accountability instruments has been conducted in Anglo-Saxon, Scandinavian and German-speaking countries ${ }^{4}$ all of them with media systems and journalism cultures with a high degree of professionalism, according to Hallin and Mancini (2004). On the other hand, in Mediterranean countries, with very few exceptions, there is little or no research on media accountability.

Spain, within the Mediterranean model, is among the states with least research on the issue. One notable exception is the work of the Journalism Research Group at the Universitat Pompeu Fabra in Barcelona ${ }^{5}$ (Alsius 2008, 2010, 2012; Alsius and Salgado 2010; Alcalà et al. 2011; Alsius et al. 2011; Ramon et al. 2016) who also contributed with the empirical data for the Spanish case to Fengler et al. (2014). Notably, Alsius et al. (2011) concluded that Spain offers an asymmetric landscape with some regions (mainly Catalonia and Madrid) having a large number of effective media accountability instruments, whereas other regions, like Andalusia and the Basque Country, only offer a 'limited example'. The authors did not expect a change in the near future to the fact that the powerful commercial television broadcasters 'display scant regard for media accountability instruments' (2011: 167).

Regarding the case of Catalonia, there is little specific research conducted and most approaches use the concepts of self-regulation and ethics - the term accountability (in Catalan 'retiment de comptes') has only very recently been introduced in the research. ${ }^{6}$ Ethical Values of Journalism is the concept used in a wider empirical research conducted on the issue. This project studied the attitudes held by Spanish journalists and the general public regarding the values and the ethical norms that affect Spanish journalism (Alsius 2010; Alsius and Salgado 2010).

Historical reviews or analyses exploring the performance of media accountability instruments in Catalonia have been conducted only for specific instruments: the code of ethics (Alsius 1998; Alsius 1999), the Catalan press council - in the form of the Information Council of Catalonia (CIC) (Navarro 1998; Oliva 2012) and the Catalan Audiovisual Council or CAC (Butti 2005; Tornos 2007; Carbonell 2009; Carreras 2013).

Despite the fact, as we will see, that Catalan journalists have 'pioneered various initiatives within Spain' regarding media accountability (Alsius 2010: 10), there is no major historical review on this case so far. In order to fill the gap, this article aims to outline the history of Catalan media accountability instruments anchored within the journalistic profession and provide an analysis of their role and contribution to the Catalan, Spanish and European contexts. We have chosen to focus on the instruments anchored within the profession because they have the highest degree of institutionalization (Eberwein et al. 2011), are the ones considered in the models analysed here (Hallin and Mancini) and constitute the 
core of the pioneering initiatives in Catalonia. One exception to this could be the inclusion in our analysis of the CAC. Independent audio-visual councils such as the CAC are still deemed powerful instruments for media accountability if they have the required competences.

For this research, two complementary methods have been used: documentary analysis and in-depth interviews. First, we gathered all the data provided by previous published documents on media accountability in Catalonia (scientific papers, reports published by the studied organizations themselves and newspaper articles). Second, we conducted in-depth interviews with key professionals involved in the creation and development of the instruments under review. The interviews shed light on the history of the Catalan instruments in three ways: by means of (1) clarifying key facts that were not clear in the public timelines of the organizations; (2) providing some key facts that did not appear in the public data for the organizations, and (3) supplying the historical context that helped us better understand the organizations' profiles.

Our research question was: to what extent do the institutional media accountability instruments in Catalonia match the Mediterranean model and fit into the Spanish Mediterranean model? To answer this question, three specific research goals were pursued: (1) to review the Hallin and Mancini's three models for western countries from the accountability instruments perspective; (2) to put the Catalan accountability system into context within the Mediterranean Model; and (3) to analyse the origin and evolution of the main institutional media accountability instruments in Catalonia.

\section{Institutional media accountability instruments in Catalonia}

\section{The three models and Catalonia}

Since the return to democracy in Spain, Catalan professionals in the world of journalism have created or collaborated in the creation of various accountability instruments. Despite their limitations and imperfections, when taken together these instruments provide a self-regulatory framework that is unparalleled in the other countries categorized by Hallin and Mancini as following the Mediterranean model. The earliest accountability instrument was the Col-legi de Periodistes de Catalunya / Association of Catalan Journalists (CPC), founded just as the Transition to Democracy was being completed in 1985. The CPC was followed by the Sindicat de Periodistes de Catalunya/Union of Journalists of Catalonia (SPC) in 1993, the Consell de la Informació de Catalunya/Information Council of Catalonia (CIC) in 1997 and the Consell de l'Audiovisual de Catalunya/Catalan Audiovisual Council (CAC) in 2000.

To put the Catalan reality into context, we can see in Tables 1, 2 and 3 the main national systems of media accountability present in the European countries analysed by Hallin and Mancini (2004).

The case of the Mediterranean model (Table 1) is notable for the fact that in 2015 not one of the countries has a state-level press council. In Spain, in 2004, the Spanish Federation of Press Associations (FAPE) created a complaints commission, the only instrument that could in anyway be equated with a press council. However, given that this complaints commission has shown very little activity and does not have a truly national reach, it has not been considered a 
genuine press council. It is not, for example, a member of the Alliance of Independent Press Councils in Europe (AIPCE). In the case of Italy, we do find that the Ordine dei Giornalisti (ODG) is a member of the AIPCE, although in fact the ODG is a corporatist state-approved institution, far closer to a professional association than to a press council. The ODG's main mission is to control entry to the profession and protect the interests of its members.

In the Spanish case it is also worth noting that there is no proper independent regulatory authority for the audio-visual sector. After more than ten years of noncompliance with the European mandate requesting that all EU members set up an independent regulatory authority for the audio-visual sector, the Spanish government passed a law (General Law of Audiovisual Communication 2010) where finally such an authority was planned (the Consejo Estatal de Medios Audiovisuales). Yet, in 2012, because of the economic recession and a lack of political will, the Spanish government gave up on the creation of a specific authority for the audio-visual sector and allocated its tasks to the National Authority for Markets and Competition. Fierce opposition from the broadcasting lobby UTECA (Associated Commercial Television Channels Union) has played a significant role in preventing the creation of a proper independent council by any Spanish government, whatever its ideological profile (Europa Press 2011). 
The most notable feature of countries aligned with the North/Central Europe model (Table 2) is that every single one has a press council. This proves that in northern countries, where the institution of the press council originates, it is still most firmly rooted.

The press council in Sweden is considered to be the world's first (1910), followed by Norway (1936), Holland (1948), Germany (1956) and Finland (1968). The countries in this model were also the pioneers in establishing an independent audio-visual authority (Switzerland and Germany since 1984, Belgium since 1987, Finland and Holland since 1988). 
Table 2: North/Central Europe or Democratic Corporatist Model. Institutional National Media Accountability Instruments (year of origin).

\begin{tabular}{|c|c|c|c|c|}
\hline Country & Journalists' associations & Journalists' unions & Press councils & Independent regulatory authorities \\
\hline Austria & - & $\begin{array}{l}\text { Gewerkschaft der Privatangestellten, } \\
\text { Druck, Journalismus, Papier (1842) (1) } \\
\text { Gewerkschaft der } \\
\text { Gemeindebediensteten Kunst, } \\
\text { Medien, Sport, freie Berufe (1888) (1) }\end{array}$ & Österreichischer Presserat (2010) & $\begin{array}{l}\text { Kommunikationsbehörde Austria - } \\
\text { KommAustria (2001). }\end{array}$ \\
\hline Belgium & $\begin{array}{l}\text { Association Générale des Journalistes } \\
\text { Professionnels de Belgique - AGJPB / } \\
\text { Algemene Vereniging van } \\
\text { Beroepsjournalisten in België - AVBB } \\
(1886)\end{array}$ & - & $\begin{array}{l}\text { Raad voor de Journalistiek (2002) } \\
\text { Conseil de Déontologie Journalistic } \\
\text { (2009) }\end{array}$ & $\begin{array}{l}\text { Conseil Supérieur de l'Audiovisuel - } \\
\text { CSA (1987) } \\
\text { Vlaamse Regulator voor de Media - } \\
\text { VRM (2005) } \\
\text { Medienrat der Deutschsprachigen } \\
\text { Gemeinschaft Belgiens (2005) }\end{array}$ \\
\hline Denmark & - & Dansk Journalistforbund (1961) & Pressenævnet (1992) & Medienaevnet (2009?) \\
\hline Finland & - & Suomen Journalistiliitto (1921) & Julkisen Sanan Neuvosto (1968) & Viestintävirasto (1988) \\
\hline Germany & $\begin{array}{l}\text { Deutscher Journalisten-Verband } \\
\text { (1949) }\end{array}$ & $\begin{array}{l}\text { Deutsche Journalistinnen und } \\
\text { Journalisten Union - DJU (1951) }\end{array}$ & Deutscher Presserat (1956) & $\begin{array}{l}\text { Direktorenkonferenz der } \\
\text { Landesmedienanstalten - DLM } \\
\text { (oldest members from first half of } \\
\text { 1980s) }\end{array}$ \\
\hline Netherlands & $\begin{array}{l}\text { Nederlandse Vereniging van } \\
\text { Journalisten - Nvj (1884) }\end{array}$ & - & Raad voor de Journalistick (1948) & $\begin{array}{l}\text { Commissariaat voor de Media - } \\
\text { CvdM (1988) }\end{array}$ \\
\hline
\end{tabular}




\begin{tabular}{|l|l|l|l|l|}
\hline Norway & Norsk Presseforbund (1910) & Norsk Journalistlag (1946) & Pressens Faglige Utvalg (1936) & Medietilsynet - NMA (2005) \\
\hline Sweden & Svenska Journalistforbundet (1901) (2) & - & $\begin{array}{l}\text { Pressens Opinionsnämnd - PON } \\
\text { (1916) }\end{array}$ & $\begin{array}{l}\text { Myndigheten för radio och tv - SBA } \\
\text { (1994) }\end{array}$ \\
\hline Switzerland & $\begin{array}{l}\text { Impressum - Les Journalistes Suisses } \\
(1883)\end{array}$ & $\begin{array}{l}\text { Schweizer Syndikat } \\
\text { Medienschaffender - SSM (1974) }\end{array}$ & $\begin{array}{l}\text { Der Schweizer Presserat / Le Conseil } \\
\text { Suisse de la Presse / Il Consiglio } \\
\text { Svizzero della Stampa (1977) }\end{array}$ & $\begin{array}{l}\text { Bundesamt für Kommunikation - } \\
\text { BAKOM; Office Federal de la } \\
\text { Communication - OFCOM; Ufficio } \\
\text { Federale delle Comunicazioni (1992) } \\
\text { Unabhängige Beschwerdeinstanz für } \\
\text { Radio und Fernsehen - UBI; l'Autorité } \\
\text { indépendante d'examen des plaintes } \\
\text { en matière de radio-télévision - AIEP; } \\
\text { Autorità indipendente di ricorso in } \\
\text { materia radiotelevisiva - AIRR (1984) }\end{array}$ \\
\\
$\begin{array}{l}\text { (1) The year corresponds to when the earliest organization in the union was founded. } \\
\text { (2) The Svenska Journalistforbundet is a professional association as well as a trade union. } \\
\text { Source: EFJ, AIPCE and EPRA. }\end{array}$ & \\
\hline
\end{tabular}


Finally, Table 3 shows that, regarding instruments of media accountability, the United Kingdom is in fact much closer to the North European model than to the Liberal one. The United Kingdom has a long-established national press council that has been revamped on various occasions and underwent a radical overhaul in 2014. This came in response to the scandal of illegal phone hacking by various newspapers in the News International group, most notably the now defunct News of the World. The lack of reaction from the then Press Complaints Commission to the allegations of phone hacking led the government to call for an enquiry. The Leveson Inquiry recommended re-establishing the press council in order to give it greater freedom from media companies and these recommendations led to the founding of the current Independent Press Standards Organization (IPSO). A second and new organization, the Press Recognition Panel (PRP) founded in 2014, was also established in response to Leveson Inquiry recommendations. If the IPSO is a watchman for journalists, the PRB watches the watchman.

In this model, Ireland has the most recently established instruments of media accountability, if we leave aside its journalists' union.

Table 3: North Atlantic or Liberal Model. Institutional National Media Accountability Instruments in Ireland and the United Kingdom (year of origin).

\begin{tabular}{|l|l|l|l|l|}
\hline Country & $\begin{array}{l}\text { Journalists' } \\
\text { associations }\end{array}$ & Journalists' unions & Press councils & $\begin{array}{l}\text { Independent } \\
\text { regulatory authorities }\end{array}$ \\
\hline Ireland & - & $\begin{array}{l}\text { National Union of } \\
\text { Journalists (UK and } \\
\text { Ireland) (1907) }\end{array}$ & $\begin{array}{l}\text { Press Council of } \\
\text { Ireland (2008) }\end{array}$ & $\begin{array}{l}\text { Broadcasting } \\
\text { Authority of Ireland - } \\
\text { BAI (2009) }\end{array}$ \\
\hline United Kingdom & - & $\begin{array}{l}\text { National Union of } \\
\text { Journalists (UK and } \\
\text { Ireland) (1907) }\end{array}$ & $\begin{array}{l}\text { Independent } \\
\text { Press Standards } \\
\text { Organization } \\
\text { IPSO (1953) }\end{array}$ & $\begin{array}{l}\text { The Office of } \\
\text { Communications } \\
\text { Ofcom (1991) }\end{array}$ \\
\hline Source: EFJ, AIPCE and EPRA.
\end{tabular}

In the case of Catalonia (Table 4), the existence of particular institutional instruments of media accountability is more closely aligned with the countries of the Corporatist or North European model than with the Mediterranean one. This similarity extends to the way in which the instruments function and also their remit. Below, we describe the main features of these four Catalan instruments. 
Table 4: Catalonia. Institutional National Media Accountability Instruments (year of origin).

\begin{tabular}{|c|c|c|c|c|}
\hline Country & $\begin{array}{l}\text { Journalists' } \\
\text { associations }\end{array}$ & Journalists' unions & Press councils & $\begin{array}{l}\text { Independent } \\
\text { regulatory } \\
\text { authorities }\end{array}$ \\
\hline Catalonia & $\begin{array}{l}\text { Col·legi de Periodistes } \\
\text { de Catalunya - CPC } \\
(1985)\end{array}$ & 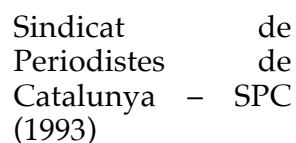 & $\begin{array}{l}\text { Consell de la } \\
\text { Informació de } \\
\text { Catalunya } \\
\text { CIC (1997) }\end{array}$ & $\begin{array}{l}\text { Consell de } \\
\text { l'Audiovisual de } \\
\text { Catalunya - CAC } \\
(2000)\end{array}$ \\
\hline
\end{tabular}

\section{The Association of Catalan Journalists (www.periodistes.org)}

The CPC grew out of a strong tradition among Catalan journalists to form associations and has its roots in the period of democracy (1931-1939) before the fascist dictatorship of General Francisco Franco (1939-1975).

As demonstrated by the historical documentation of the CPC, in Barcelona in the 1930s there were up to five professional associations for journalists. From 1939, when the civil war ended, the dictatorship purged the journalistic sector. Organizations with a pro-Catalan profile were forced to disband, whereas the rest were absorbed into the Associació de la Premsa Diària de Barcelona/Barcelona Daily Press Association (APDB) - an organization created in 1909. From 1939 on, the APDB would function as a tool of the Franco regime to control the way journalists worked. It was re-democratized after the political Transition to Democracy, and in 1985 elected its president democratically. That same year the new APBD president, backed by a group of high-profile Catalan journalists, managed to get the Law for the Creation of the Association of Catalan Journalists brought before the Catalan Parliament. It was approved unanimously.

The formula adopted for the new institution - that of a professional college (collegi) rather than an association (associació) - shows how keen the founders were to distance themselves from the organizational model used under the dictatorship (I1, I3, I4). At the end of the Franco dictatorship and during the era of Transition to Democracy in Spain, it was the professional Catalan colleges (of lawyers, doctors, engineers, etc.) that had taken a strong stand in favour of democracy and in defence of the Catalan language (I6, I7, I8). By contrast, the association model was seen as having been linked to the Franco regime, to private interests and also had a more limited remit. While other types of association did appear within Catalan journalism, it is the CPC that has been the most widely and consistently supported institution among journalists (Alsius 2010: 10).

From the beginning, the CPC primarily encouraged freedom of information, the raising of professional standards, ongoing training, the protection of journalists and the reporting of bad practice. So far, it has brought about the passing of a regulatory law on the matters of conscience clause (1997); created an international press centre in Barcelona (1998); and drawn up its own deontological code, inspired by the great transnational codes of the International Federation of Journalists, UNESCO and the Council of Europe (1992) (I1, I6). It pushed for the creation of the SPC (1992) and the CIC (1997, known as FCIC since 1999). The $\mathrm{CPC}$ has taken a stand on gender equality and the need to keep political influence 
out of journalism (e.g., reporting on the existence of electoral blogs) and has published guides on even-handed journalistic coverage, military conflict and cultural diversity.

The main forerunner of the CPC, the APDB, dates back almost as far as the Press Association of Madrid (founded in 1895), which was the first instrument of selfregulation for journalists in Spain. In all the regions of Spain, apart from Catalonia, most of the press associations that had existed throughout the Franco dictatorship continued to exist, although in 1992 most were grouped under the umbrella of the Spanish Journalists' Associations Federation (FAPE). In 1995, the FAPE began recommending the creation of associations in the form of colleges (colegios) in all the autonomous regions of Spain, considering the college model to offer "more possibilities of professional representation and the best legal standing' (González Díaz de Ponga 2013). Despite this, twenty years on, the creation of a journalists' college has only been approved in five out of the remaining sixteen autonomous communities. ${ }^{10}$ Of these five, four have continued to use the deontological code and arbitration service of the FAPE. Only the Galician and Catalan colleges have their own complaints service.

The CPC has further traits that distinguish it from the other five journalists' colleges that existed in Spain in 2016. First, the statutes of the CPC regard promoting the Catalan language to be a function of the organization. The aim of promoting a particular language is not shared by any of the other colegios in Spain, including those in regions that have their own language, namely Galicia and the Basque country. In addition, the CPC has its own deontological code, which it has refined with the addition of various annexes to reflect the new challenges faced by journalism professionals working in Catalonia. The CPC's deontological code was the first declaration of principles for the journalistic profession to be drafted in the Spanish state (in 1992) and takes as its reference the most important transnational codes previously mentioned.

The singularity of the CPC probably explains why it is absent from the Spanish association (FAPE) but instead participates directly, on occasion, in international bodies such as the International Federation of Journalists (IFJ) and the European Federation of Journalists (EJF) (I1, I6). ${ }^{11}$

\section{The Union of Journalists of Catalonia (www.sindicatperiodistes.cat)}

The SPC was founded in 1993 with the primary mission of securing decent employment conditions for professionals working in the information sector and offering union representation to professionals within their companies. Before 1993 these issues had been channelled through the Defence Committee of the CPC, even though dealing with such matters was not specified in the CPC's statutes. It was the insistence of various professionals from the sector that pushed forward the creation of the SPC (I1). The SPC was the first professional union to appear at the Spanish-state level and later served as a model for the founding of other unions at the regional level. ${ }^{12}$ In 2001 the Federation of Journalists' Unions (FESP) was created at the state level and incorporated independent unions from the autonomous regions. This also meant that individuals based in autonomous regions where there was no union affiliated to the federation could still access direct representation. The SPC became integrated with the FESP from that point. 
While the explicit primary function of the SPC was to defend information workers' rights, in fact it has also played an integral part in enabling journalists to uphold media accountability. The SPC, together with the FESP, has encouraged highly relevant state-level initiatives relating to the model of public media and the need to regulate the rights and responsibilities of journalists. In 2003, together with other members of the Forum of Journalists' Organizations, they successfully pushed for a debate in the Congress of Deputies in Madrid to discuss the Statute concerning Professional Journalism and the Law of Journalists' Rights and Responsibilities (reconstituted in 2010 as the Law Guaranteeing the Public's Right to Information). In April 2016, however, this regulation still does not have a date set for approval. Nonetheless, the drafting of this legislation was an important step for those organizations determined to bring Spain up to the level of other European countries in terms of the legal tools on offer to ensure media accountability. ${ }^{13}$

\section{The Catalan Press Council (fcic.periodistes.org)}

In 1995, the CPC created the Catalan Press Council (Consell de la informació de Catalunya, CIC; FCIC since 1999) following the model of the then British Press Complaints Commission. The addendum to the Catalan deontological code of 1992 had already flagged up the need to create a body charged with ensuring compliance with the code (Alsius 2012). The FCIC was formally constituted in 1997 and in 1999 attained its status as a foundation to undertake private and independent arbitration.

Later in 2004, the FAPE created the Complaints Commission at the Spanish-state level and from 2012 this functioned, to some extent, as a press council. However, some still see Catalonia as the only nation in Southern Europe with a genuine press council (Eberwein et al. 2011) and it is the FCIC and not the state-level complaints commission that has been incorporated into the Alliance of Independent Press Councils of Europe. ${ }^{14}$ Among the other countries that conform to Hallin and Mancini's Mediterranean model, Greece has no press council; Portugal and Italy partially incorporate the functions of a press council into their independent regulator and journalists' association, respectively. In France, although some professionals did push for the Association for the Preparations Regarding the Creation of a Press Council in 2006, this commission was still in a phase of reflection in April 2016 and no council has yet been created. The case in Catalonia is also unique in that it is the only stateless nation in Europe with a press council. Only in Belgium are there independent regional press councils (one for the Walloon region and another for the Flemish region; Eberwein et al. 2011).

The FCIC modelled itself on the then British Press Complaints Commission, where the will for self-regulation was born out of an attempt by professionals and information companies to keep government intervention out of the media. In fact, the creation of the FCIC was supported by the presidents of the press councils of Britain and Sweden, who helped with the planning of the council (Alsius 2011). Of the different models proposed for the FCIC, a concept of threelegged participation was chosen, in which media professionals, media companies and their audiences are all represented on the FCIC's thirteen-member board and audience representatives must outnumber media professional representatives (Alsius 2011). Establishing a fair representation on the basis of universal suffrage ran the risk of politicizing the body, as clearly happened with 
the CAC. Therefore, the FCIC adopted a policy of qualitative co-option. Companies have limited direct representation on the council but those who decide to accept the FCIC's moral authority contribute to its functioning with an annual subscription proportional to their size and audience (Alsius 2012). In 2015, according to its website, the FCIC had 80 companies and other groups signed up as members. These included media entities from the fields of written communication, radio, television, websites and other communication entities supporting the principles set out in their de-ontological code for journalists.

The functions of the FCIC basically coincide with those of the AIPCE (I3, I6, I7), although the FCIC has a smaller budget than its European counterparts (I3, I7). The requirements of the AIPCE, a network of independent regulators of content for the European press and broadcast media, include the following: agreeing on and instigating a best practice code, investigating complaints from the public regarding editorial content of communication media and defending the freedom of the press (Alsius 2012).

The FCIC is also an instrument of self-regulation and therefore its recommendations carry the weight of moral authority. Any individual or entity can present a complaint to the FCIC regarding an infringement committed by a professional or a communication media body and request its arbitration service. Between 1997 and 2015, the FCIC opened 645 expedients (FCIC 2016).

\section{The CAC (www.cac.cat)}

Consell Audiovisual de Catalunya/The Catalan Audiovisual Council (CAC) is the last of the institutional instruments of media accountability to have been introduced in Catalonia. It was the first of its type in the Spanish state and today, of the other autonomous communities in Spain, only Andalusia has a similar instrument. The CAC was created in 2000 with a limited remit and then in 2005 took on its current functions.

The need to create a body like the CAC was recognized in 1996 by a number of academics, mainly from the Catalan political class (I4, I8). At the beginning, the body was seen as a good tool for protecting the use of Catalan in audio-visual communication media. Following the reform it underwent in 2005, the CAC broadened its functions, inspired by the models used in Britain and, above all, in France (I2, I4, I5, I8). Its role expanded so that as well as assessing and controlling content it also created and enforced regulations.

At the time of writing this article (April 2016), the CAC has the aim and functions of a classic independent regulator, although with the obvious limitations of operating in a nation within a plurinational state rather than at the Spanish-state level. This means that the CAC has no control over media that operate through concessions run from Madrid (for these operators the CAC only has competences over the content that is emitted exclusively for Catalonia). Given the absence of a state-level independent regulator, this has meant that for years Catalan audiovisual media have been subject to control and vigilance, which is lacking for those operators with concessions for services awarded from Madrid.

The mission of the CAC is to check that regulations, both national and European, regarding rights and freedoms in the audio-visual sector are being respected. It has four main functions: to assess the suitability of concessions to offer audio- 
visual services in Catalonia; to check that broadcasted content complies with regulations; to produce reports and codes of practice; and to promote coregulation, self-regulation and arbitration. It is in this fourth function that the CAC could be said to act as an instrument for media accountability. It sets out to encourage self-regulation, offer mediation and accept complaints and queries from citizens regarding audio-visual media that fall within its remit. In 2013, for example, it received 286 communications including complaints and queries regarding a range of different broadcasts and areas of concern. The area generating most correspondence from the public related to the protection of children and young people (CAC 2013).

Despite the consolidation of the $\mathrm{CAC}$, its first fifteen years have been fraught with controversy. While its formula of electing members through a parliamentary vote is common among independent regulatory authorities across Europe, the partisan nature of some CAC councillors (connected directly or indirectly to Catalan political parties) has prompted claims of politicization (I1, I2, I4). This politicization of the CAC dovetails with the political intervention that is typical of media systems in Hallin and Mancini's Mediterranean model. However, it should be stressed that there have been varying levels of politicization throughout the CAC's fifteen-year history.

Despite its failings, the CAC does still constitute an instrument of media accountability that is not found in the rest of Spain in April 2016, except in Andalusia through the Audiovisual Council of Andalusia.

\section{Discussion}

Hallin and Mancini's three models (2004) offer a useful set of parameters for categorizing media systems. Yet when applied to nation states, which are not only multicultural but also multinational societies, results show that this categorization provides only a limited analytical framework.

This article has analysed whether Catalonia, a stateless nation within Spain, fits into the Spanish, i.e., the Mediterranean, model regarding media accountability. We have taken the level of professionalization in a country's media system to be an indicator of that country's media accountability. In this respect, while the Mediterranean model demonstrates a low level of professionalization, Catalan journalistic culture shows a level of commitment to a professional culture more aligned with the standards of the other two models.

Notably, as Hallin and Mancini stress, Mediterranean countries are characterized by a general absence of formal, independent systems of accountability. The absence of these organisms, common among most liberal democracies, indicates a lack of consensus on ethical standards in respect to the media. By contrast, in Catalonia there is an audio-visual regulatory council (still without a Spanish equivalent, some fourteen years after its creation) a journalists' union and a press council (the latter still lacking a fully operative Spanish equivalent). In fact, Catalonia is the only nation in Southern Europe with a genuine press council. Likewise, the Catalan Union of Journalists and the Association of Catalan Journalists were the first of their type in Spain. They were preceded only by the local Press Association of Madrid - an organization with a limited remit that is today promoting the creation of journalists' associations structured along the 
lines of the Catalan one. Also, the ethical code created in 1992 by the Association of Catalan Journalists was the first of its type in Spain.

These institutions are not without their flaws or constraints. As mentioned, the CAC has been criticized for being politicized (Ara 2012) and has no competences over audio-visual broadcasters licensed by the Madrid government. The Association of Catalan Journalists has also received strong criticism for its lack of internal ideological pluralism (Navarro 2015), and the Union of Journalists and the Catalan Press Council have very limited budgets and resources. Yet together they constitute a unique compendium of institutional media accountability tools in a South European nation, inspired by the best international practices. To assess the impact these institutions have on media coverage in Catalonia is beyond the scope of this article, yet this institutional accountability context is at odds with the Spanish one, in which Catalonia is embedded. This dissonance has led to a significant imbalance between the various media stakeholders in Catalonia; Catalan media and media professionals are submitted to greater vigilance and control than media produced from Madrid even when they share the same communicative space.

Further research is needed to provide an explanation for the different level of development of the Catalan institutional instruments of media accountability in contrast with other countries of Southern Europe, and yet we suggest the cultural approach may provide useful analytical tools. The culturalist approach is actually claimed by some authors (Eberwein et al. 2011; Fengler et al. 2014) to be essential and a perspective missing from Hallin and Mancini's models, which are 'mostly concerned with journalism's dynamic vis-à-vis the state and political powers' (Fengler et al. 2014: 178-79). Including the cultural domain in the analysis might provide an insight into attitudes, perceptions and practices that can be very useful to the understanding of similarities and differences, proximities and distances among communicative realities.

The analysis carried out here in no way wishes to suggest that professionals working in the Catalan media are better than their colleagues in the rest of Spain or in other Mediterranean countries. However, it is obvious that certain individuals and the Catalan journalistic profession in general have been pioneering in various media accountability initiatives. These set Catalonia apart from the other countries identified by Hallin and Mancini as aligned with the Mediterranean model of media systems, including Spain.

\section{References}

Alcalà, F., Alsius, S. and Salgado, F. (2011), 'News ethics in borderland country', Quaderns del CAC, XIV:36, pp. 19-30.

Almiron, N. (2010), Journalism in Crisis: Corporate Media and Financialization, Cresskill, NJ: Hampton Press.

Alsius, S. (1998), Ètica i periodisme, Barcelona: Pòrtic. (1999), Codis ètics del periodisme televisiu, Barcelona: Pòrtic. 
(2008), 'Luces y sombras de la ética de la comunicación', in J. Duran and L. Sánchez (eds), Industrias de la comunicación audiovisual, Barcelona: Universitat de Barcelona, pp. 333-58.

(ed.) (2010), The Ethical Values of Journalists, Barcelona: Generalitat de Catalunya.

(2011), 'Cap a una gran base de dades per a l'estudi de l'ètica periodística', Periodística, 13, pp. 27-57.

(2012), La millor llei de premsa és la que no existeix? Donant-li voltes a la regulació i l'autorregulació, Bellaterra: Incom-UAB, http://www.portalcomunicacion.com/lecciones.asp?aut=80\&lng=cat. Accessed 15 February 2015.

Alsius, S. and Salgado, F. (eds) (2010), La ética informativa vista por los ciudadanos: Contraste de opiniones entre los periodistas y el público, Barcelona: UOC.

Alsius, S., Mauri, M. and Rodríguez Martínez, R. (2011), 'Spain: A diverse and asymmetric landscape', in T. Eberwein, S. Fengler, E. Lauk and T. Leppik-Bork (eds), Mapping Media Accountability - in Europe and Beyond, Köln/Cologne: Halem, pp. 155-67.

Ara (2012), 'El Col-legi de Periodistes: "Prou de la politització dels òrgans de control audiovisuals"', 4 July, http://www.ara.cat/politica/Collegi_Periodistes_Catalunya-polititzacio-control-audiovisual_0_730727101.html.

Accessed 30 April 2016.

Butti, D. (2005), 'El Consejo del Audiovisual de Cataluña: Hacia la autorregulación a través de los consensus', Telos: Cuadernos de comunicación e innovación, 62, pp. 147-49.

CAC (2013), Informe Anual 2013, Barcelona: Consell de l'Audiovisual de Catalunya.

Carbonell, J. M. (2009), ‘Las autoridades independiente en la regulación del sector audiovisual. El consejo del audiovisual de Cataluña', in C. Pauner, and B. Tomás (eds), Las administraciones independientes, Valencia: Tirant lo Blanch, pp. 21-26

Carreras, Ll. de (2013), 'El Consejo Audiovisual de Catalunya', in J. C. Gavara de Cara (ed.), Las autoridades independientes de control de los medios de comunicación audiovisual, Barcelona: Bosch, pp. 111-138

Christians, C. G., Glasser, T. L., McQuail, D., Nordenstreng, K. and Whitel, R. A. (2009), Normative Theories of the Media: Jorunalism in Democratic Societies, Urbana and Chicago: The University of Illinois Press.

Civil i Serra, M., Blasco Gil, J. J. and Guimerà i Orts, J. A. (eds) (2015), Informe de la comunicació a Catalunya 2013-2014, Barcelona: Generalitat de Catalunya. Col·lecció Lexikon Informes.

Col-legi de Periodistes (2015), 'Periodistes. 25 anys construint el col-legi', http:/ / cronologia.periodistes.org. Accessed 9 March 2015.

Eaude, M. (2008), Catalonia: A Cultural History, Oxford: Oxford University Press.

Eberwein, T., Fengler, S., Lauk, E. and Leppik-Bork, T. (eds) (2011), Mapping Media Accountability - in Europe and Beyond, Köln/Cologne: Halem.

Europa Press (2011), 'Las cadenas se oponen a un consejo audiovisual que supervise los contenidos', Telecinco, http://www.telecinco.es/telemania/cadenas- 
Consejo-Audiovisual-supervise-contenidos 0 1240050039.html. Accessed 21 June 2015.

FCIC (2016), 'Informe memòria 2015', Fundació Consell de la Informació de Catalunya, Barcelona.

Fengler, S., Eberwein, T., Mazzoleni, G. and Porlezza, C. (2014), Journalists and Media Accountability: An International Study of News People in the Digital Age, New York: Peter Lang.

Fernández-Alonso, M. I. and Fernández-Viso, A. (2012), 'Internal pluralism in the governance of public service broadcasters in Spain and the role of social groups and professionals. The case of RTVE1', Comunicación y Sociedad, 15:2, pp. 203-30.

FESP (2007), 'Periodistas a la pieza en Europa y en España', Informe elaborat per Patricia Estévez, Jarimo Morga Manzanares and Dardo Gómez, http:/ / www.sindicatperiodistes.cat/sites/default/files/documents/EI_Compa rativa_periodistes_a_la_pec-a.pdf. Accessed 21 June 2015.

Fontana, J. (2016), La formació d'una identitat, Una història de Catalunya, Barcelona: Eumo Editorial.

Gifreu, J. (2006), La pell de la diferència, Barcelona: Pòrtic.

González Díaz de Ponga, E. (2013), 'Potenciar gremio y calidad professional: Objetivos de los colegios de periodistas', Profesiones, 145, p. 48.

Hallin, D. and Mancini, P. (2004), Comparing Media Systems: Three Models of Media and Politics, Cambridge: Cambridge University Press.

Harris, S. (2014), Catalonia is not Spain: A Historical Perspective, Barcelona: 4Cats Books.

Mansell, R. and Raboy, M. (2014), The Handbook of Global Media and Communication Policy, Malden, MA: Wiley-Blackwell.

Mauri-Ríos, M. and Ramon-Vegas, X. (2015), 'Nuevos sistemas de rendición de cuentas de la información periodística. Exploración del escenario online español', El Profesional de la Información, 24:4, pp. 1699-2407.

Navarro, V. J. (1998), ‘Comentarios a la creación del Consejo de la Información de Cataluña', Revista Latina de Comunicación Social, 3, http:// www.revistalatinacs.org/z8/latina_art30.pdf. Accessed 12 July 2016.

(2015), 'La dictadura mediática en Catalunya y en España', Publico.es, http:/ / blogs.publico.es/vicenc-navarro/2015/09/25/la-dictadura-mediatica-encatalunya-y-en-espana/. Accessed 30 April 2016.

Oliva, L. 1. (2012), 'El Consell de la Informació de Catalunya, com a sistema de rendiment de comptes dels mitjans', Comunicació: Revista de Recerca i d'Anàlisi, 30:2, pp. 9-32.

Ramon-Vegas, X. and Mauri-Ríos, M. (2016), 'Transparencia, autorregulación, rendimiento de cuentas y participación del público para mejorar la calidad periodística: Análisis de las experiencias pioneras de Mural.com, Rue89.com y TexasTribune.org', Comunicación y Sociedad (Mexico), 25, pp. 101-25.

Schlesinger, P. (2009), 'Cultural and communications policy and the stateless nation', Catalan Journal of Communication and Cultural Studies, 1:1, pp. 9-14.

Sobrequés, J. (2007), History of Catalonia, Barcelona: Editorial Base. 
Tornos, J. (2007), 'El Consell de l'audiovisual de Catalunya', Revista catalana de dret public, 34, pp. 157-86.

Zallo, R. (2013), 'Polítiques de comunicació a les nacions sense estat. El cas espanyol', in M. Civil i Serra, J. J. Blasco Gil and J. A. Guimerà i Orts (eds), Informe de la comunicació a Catalunya 2011-2012, Barcelona: Generalitat de Catalunya. Col·lecció Lexikon Informes.

\section{Contributor details}

Núria Almiron is a Senior Lecturer at the Department of Communication of Universitat Pompeu Fabra, Spain. She has previously taught at Universitat Autònoma de Barcelona and Universitat de Girona. Her current research topics are focused on the political economy of communication, the ethics of mediation, discourse analysis and interest groups from a non-anthropocentric, nonspeciesist perspective. Her work has appeared in Journalism Studies, Environmental Communication, International Journal of Communication, International Communication Gazette, American Behavioral Scientist and others. Her latest books are Journalism in Crisis (Hampton Press, 2010) and Critical Animal and Media Studies (Routledge, 2015, as co-editor). She is a member of UNICA research group at UPF.

Marta Narberhaus (Barcelona, 1984) is a researcher and lecturer at the Department of Communication of Universitat Pompeu Fabra, Spain, where she teaches in the area of journalism. MA in Social Communication and BA in Journalism and Art History, She is currently pursuing a Ph.D. in Communication. Before starting her academic career, she worked in various media (radio, television, print and the Internet), and now combines research on journalism ethics and quality of information with occasional collaborations in local media.

Marcel Mauri i de los Ríos (Badalona, 1977) is a senior lecturer at Universitat Pompeu Fabra. He holds a Ph.D. in Social Communication from Pompeu Fabra University, since 2010. He is a historian, journalist and professor of History of Journalism and Journalistic Ethics in the Department of Communication at the UPF. He also acts as Ethics and Information Law consultant at the Open University of Catalonia (UOC, for its initials in Catalan). He has published articles and books on the history of journalism and journalistic ethics - the main research lines he is devoted to.

\section{Contact:}

Núria Almiron, Universitat Pompeu Fabra, Roc Boronat 138, Barcelona 08018, Spain.

E-mail: nuria.almiron@upf.edu

Marta Narberhaus, Universitat Pompeu Fabra, Roc Boronat 138, Barcelona 08018, Spain.

E-mail: marta.narberhaus@upf.edu

Marcel Mauri, Universitat Pompeu Fabra, Roc Boronat 138, Barcelona 08018, Spain.

E-mail: marcel.mauri@upf.edu 


\section{Notes}

${ }^{1}$ After separatist parties won 72 of the 135 Catalan Parliament seats in the 2015 polls, Catalonia started the process of creating a state.

${ }^{2}$ According to Hallin and Mancini (2004), the Democratic Corporatist model is characterized by a high level of development of the press market, of political parallelism, of professionalization and of State intervention. The Liberal model is characterized by a high level of development of the press market and of professionalization and a low level of political parallelism and State intervention. The Mediterranean model has a high level of political parallelism and State intervention but low levels of professionalization and development of the press market.

${ }^{3}$ The term 'Spanish culture' is more accurately rendered 'Castilian culture', since it is Castile, the central region of Spain, that has imposed its language, culture and politics on the other Spanish territories since the creation of modern Spain between the eighteenth and nineteenth centuries.

${ }^{4}$ See Eberwein-and Fengler et al. (2014) for a literature review on the Anglo (11 et al. (20 -Saxon, Scandinavian and German research, mostly related to the study of long .established (institutional) instruments such as press councils and codes of ethics

${ }^{5}$.www.eticaperiodista.org See

${ }^{6}$-The research presented in this article has been conducted as part of the first goverment funded project in Spain to include "media accountability" in its title (see Funding in this .(article

${ }^{7}$ The authorshave conducted interviews and consultation with Salvador Alsius (I1), Santiago Ramentol (I2), Llúcia Oliva (I3), Josep Gifreu (I4), Victoria Camps (I5), Josep Maria Cadena (I6), Roger Jiménez (I7), and Joan Corbella (I8).

${ }^{8}$ See http://www.odg.it

${ }^{9}$ atalan Journalists is protected under Law 7/2006 of May Currently the Association of C st regarding the practice of qualified professionals and professional colleges, modified 31 .by decree $3 / 2010$ of October 5 th

${ }^{10}$ the Catalan The journalists' colleges approved in Spain up until 2015, in addition to one, are: Galicia (1999), Murcia (2007), Andalusia (2012), the Basque County (2012), .(Castile and Leon (2012

${ }^{11}$ According to the statutes of the IJF and the EJF only union associations can be cific activities with the IFJ, as members. Nonetheless, the CPC has taken part in spe .recalled by at least one of its deans, Salvador Alsius, in a personal interview

${ }^{12}$ Madrid Union of Journalists (1999); Union of Journalists of Andalusia (1999); Union of Journalists of the Balearic Islands (2000); La Rioja Union of Information Professionals (2001); Union of Communication Professionals from the Canary Islands (2003); and the Union of Journalists of Galicia (2005).

${ }^{13}$ A study by the FeSP in 2007 on the legislation of journalists in Europe cited the us situation of piece work journalists and freelancers in Spain compared with precario those in other European countries, and blamed they lack appropriate regulation (FeSP .)(2007

${ }^{14}$ See Alliance of Independent Press Councils of Europe (http://www.aipce.net/). 